George Sand 


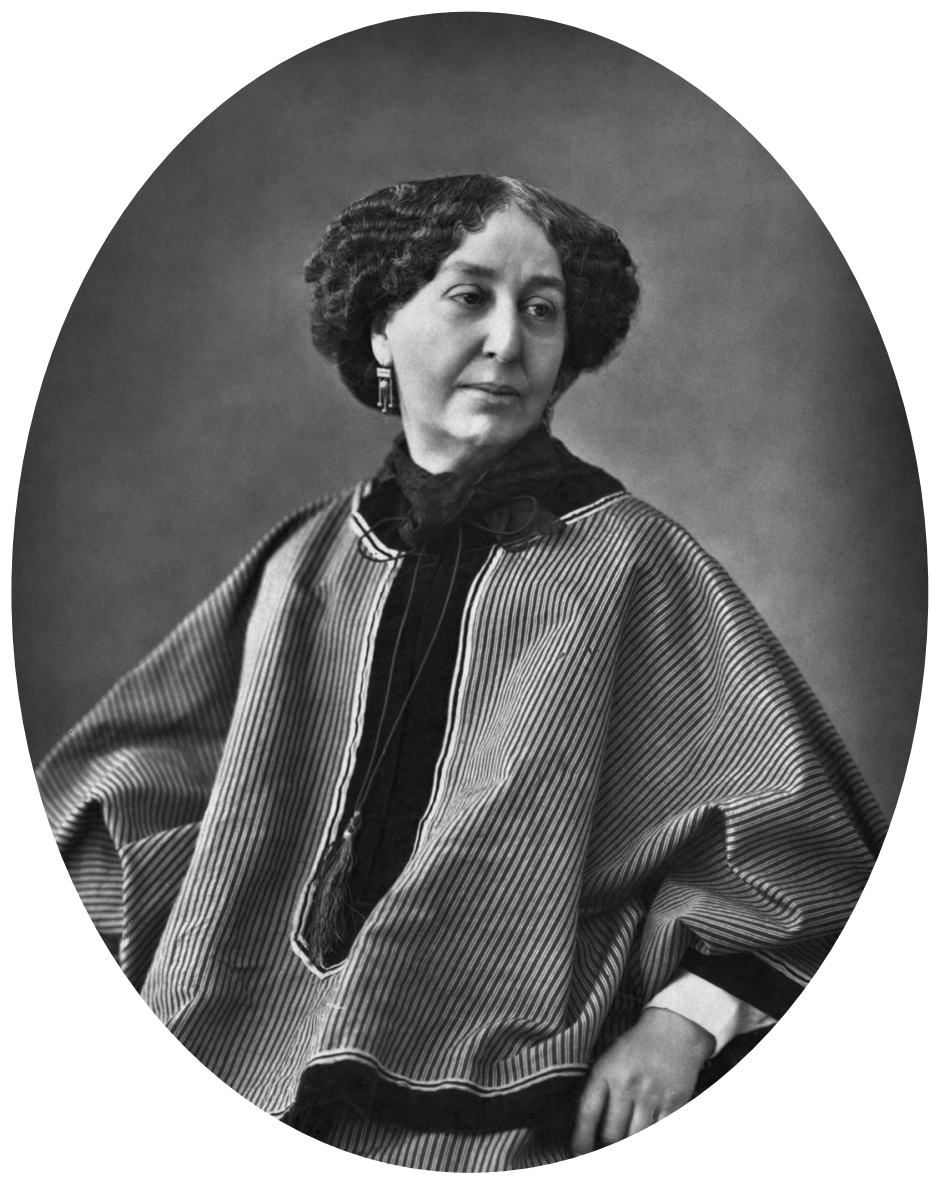




\section{George Sand}

MARTINE REID

Translated with an introduction by

Gretchen van Slyke

The Pennsylvania State University Press

University Park, Pennsylvania 
Frontispiece: Nadar, portrait of George Sand, I 864. Photo:

Wikimedia Commons (Ministère de la Culture-Médiathèque de l'architecture et du patrimoine-diffusion RMN).

Library of Congress Cataloging-in-Publication Data

Names: Reid, Martine, author. I Van Slyke, Gretchen Jane, translator.

Title: George Sand / Martine Reid ; translated with an introduction by Gretchen van Slyke.

Other titles: George Sand. English

Description: University Park, Pennsylvania : The Pennsylvania State University Press, [2018] I Originally published in French: Paris : Gallimard, 20I3. I Includes bibliographical references and index. Summary: "A biography of the celebrated nineteenth-century author George Sand. Examines her public image, her relationships with her husband, lovers, and children, and her lifelong political commitment"-Provided by publisher.

Identifiers: LCCN 20 I 7060 I I I ISBN 97802 7 I08 I069 (cloth : alk. paper)

Subjects: LCSH: Sand, George, I 804-I 876. I Novelists, FrenchI 9 th century-Biography.

Classification: LCC PQ24I 2 .R45I3 20 I 8 I DDC 843/.8 [B] — dc2 3

LC record available at https://lccn.loc.gov/20 I 7060 I I I

(C) Éditions Gallimard, Paris, 2013.

Copyright (C) 2018 The Pennsylvania State University

All rights reserved

Printed in the United States of America

Published by The Pennsylvania State University Press,

University Park, PA I6802-1003

The Pennsylvania State University Press is a member of the Association of University Presses.

It is the policy of The Pennsylvania State University Press to use acid-free paper. Publications on uncoated stock satisfy the minimum requirements of American National Standard for Information Sciences-Permanence of Paper for Printed Library Material, ANSI Z39.48-I992. 